\title{
Floral anatomy and development of Saxofridericia aculeata (Rapateaceae) and its taxonomic and phylogenetic significance
}

\author{
${\text { Renata C. } \text { Ferrari }^{1} \text { (I) }}$ Aline Oriani $^{1}$
}

Received: 9 May 2016/Accepted: 13 October 2016/Published online: 28 October 2016

(C) Springer-Verlag Wien 2016

\begin{abstract}
Floral anatomy and development of Saxofridericia aculeata Körn was studied in a comparative approach to contribute to the understanding of the family. Flowers at different developmental stages were analysed with light and scanning electron microscopy, and the nature of the exudate secreted by the floral trichomes was investigated by histochemical tests. The anatomical characteristics observed in S. aculeata flowers were compared with those from other Rapateaceae species by a cluster analysis (UPGMA). The dendrogram generated reflects the groupings that emerged in phylogenetic molecular analyses, highlighting the usefulness of floral anatomy for taxonomy and for the understanding of infrafamilial relationships. The exudate secreted by the trichomes has a polysaccharidic composition. Such trichomes (colleters) occur in the sepals, petals, filaments and around the gynoecium; they are initiated at mid-stage of floral development and are an apomorphy of the family. The flowers are pentacyclic, presenting three initially free sepals, petals, stamens and carpels that mature in a centripetal order. The connate portion of the corolla, which is also adnate to the stamens, has a late development by zonal growth. Gynoecium formation is a combination of postgenital and congenital fusion processes. Data on floral organogenesis of Rapateaceae are first reported here and support the early diverging position of the family in Poales, close to Bromeliaceae.
\end{abstract}

Handling editor: Peter K. Endress.

Renata C. Ferrari

renata.callefe@gmail.com

1 Departamento de Botânica, Instituto de Biociências,

Universidade Estadual Paulista (UNESP),

C. Postal 199, Rio Claro, SP 13506-900, Brazil
Keywords Cluster analysis - Colleter - Monotremoideae · Postgenital intercarpellary fusion · Rapateoideae .

Saxofridericioideae

\section{Introduction}

Rapateaceae have a controversial phylogenetic position in Poales. The family generally appears in an early diverging position, closely related to Bromeliaceae and Typhaceae (Bremer 2002; Davis et al. 2004; Linder and Rudall 2005; Chase et al. 2006; Givnish et al. 2010). However, in the most recent and largest molecular phylogenetic analysis of Poales, based on $r b c \mathrm{~L}$ and $n d h \mathrm{~F}$ sequence data, Rapateaceae emerge as sister to Mayacaceae, close to Juncaceae, Thurniaceae and Cyperaceae, although with low support (Bouchenak-Khelladi et al. 2014).

Rapateaceae occur almost exclusively in tropical South America, except for the African and monotypic genus Maschalocephalus (Stevenson et al. 1998; Berry 2004). The family comprises 17 genera and ca. 100 species, of which around 40 are found in Brazil, mainly in the Amazon region (Stevenson et al. 1998; Givnish et al. 2000, 2004; Berry 2004; Monteiro 2015). Rapateaceae are divided into three subfamilies and five tribes: Rapateoideae (Rapateeae), Monotremoideae (Monotremeae) and Saxofridericioideae (Saxofridericieae, Schoenocephalieae and Stegolepideae) (Givnish et al. 2004).

Saxofridericia is the only genus of the tribe Saxofridericieae and includes around 11 species (Berry 2004; Givnish et al. 2004). The genus is characterised by globose to hemispheric inflorescences completely enclosed by two saccate involucral bracts, which are perforated by the elongating sepal tips as the flowers develop (Berry 
2004). Saxofridericia aculeata Körn. is the most common species of the tribe, occurring in six South American countries, and is distinguished from the remaining Saxofridericia by constricted and spinescent leaves (Maguire 1958; Berry 2004). It is herbaceous, with a short rhizomatous stem that bears distichous long leaves and an axillary inflorescence peduncle (Maguire 1958; Berry 2004).

Flower anatomy of Rapateaceae has been studied in different genera of Rapateeae, Monotremeae and Stegolepideae for taxonomic purposes by Oriani and Scatena (2013). These authors highlighted the constancy of flower anatomy at generic level and its importance to subfamilies, tribes and genera identification. They also pointed to the presence of floral secreting trichomes (colleters) as an apomorphy of the family. Flowers of Rapateaceae are known for having abundant amounts of mucilage covering its floral buds and inflorescences (Maguire 1958, 1965; Stevenson et al. 1998; Berry 2004); however, there are no studies characterising this exudate.

The floral architecture of angiosperms has been studied under many different points of view, such as genomics, genetics, morphology and anatomy, that combined are important to elucidate the floral evolution (Soltis et al. 2002; Endress 1994, 2011). In addition, the study of flower development adds another dimension for the understanding of phylogenetic relationships among groups, since it allows the identification of homologies (Endress 1990; Tucker 1992, 1997). Also, the understanding of initiation and post-initiation events during floral morphogenesis can reveal fusion events during compound organs formation (Kaplan 1968; Verbeke 1992). There are several studies on floral anatomy and development of Poalean families (e.g. Ronse Decraene et al. 2002; Sajo et al. 2004, 2007; Rudall et al. 2005; Vrijdaghs et al. 2005, 2009; Sokoloff et al. 2009; Remizowa et al. 2012; Reynders et al. 2012; Sajo and Rudall 2012), but for Rapateaceae, there is a lack of ontogenetic information.

In this work, we analysed the floral anatomy and development of Saxofridericia aculeata (Saxofridericieae), aiming to characterise the species and describe, for the first time, the nature of flower exudate and the flower development in Rapateaceae. Considering that systematic studies and hypotheses on phylogenetic relationships among taxa have traditionally been based on comparative morphology and anatomy, we also performed a cluster analysis (UPGMA) based on the flower characteristics of Rapateaceae, including information presented here and by Oriani and Scatena (2013) for other genera, highlighting the usefulness of these attributes to elucidate the infrafamilial relationships.

\section{Materials and methods}

Samples of Saxofridericia aculeata were collected in the Amazon Forest understory at Reserva Florestal Adolpho Ducke (Manaus, Amazonas, Brazil). Vouchers were deposited at Herbarium Rioclarense of the Universidade Estadual Paulista (UNESP), Rio Claro Campus (Coan et al. 248). Flowers at different developmental stages were fixed in FAA 50 (37\% formaldehyde, glacial acetic acid, 50\% ethanol, 1:1:18 v/v) (Johansen 1940) and then transferred into $70 \%$ ethanol. More than five individuals were analysed anatomically.

Morphological aspects of the flowers were observed under a stereomicroscope (Leica MZ6) and documented using a digital camera (Canon, PowerShot S80). For the analyses under light microscopy, the material was dehydrated in a n-butyl alcohol series, embedded in (2-hydroxyethyl)-methacrylate (Leica Historesin Embedding Kit) (Gerrits and Smid 1983) and sectioned at 5-10 $\mu \mathrm{m}$ on a rotary microtome (Leica RM 2245). These sections were stained with periodic acid-Schiff's reagent (PAS) and Toluidine Blue (Feder and O'Brien 1968) and mounted on slides using Entellan (Merck). The following histochemical tests were performed: Toluidine Blue (O’Brien et al. 1964), Sudan IV for total lipids (Jensen 1962), periodic acid and Schiff's reagent (PAS) for polysaccharides (Feder and O'Brien 1968), Coomassie Brilliant Blue for proteins (Fisher 1968), Ruthenium Red for pectins, potassium chloride (IKI) for starch grains, $10 \%$ aqueous $\mathrm{FeCl}_{3}$ for phenolic compounds, 5\% tannic acid and $3 \% \mathrm{FeCl}_{3}$ for mucilage (Johansen 1940). Such tests were applied in sections obtained from microtome and also in paradermal handmade sections of sepals, petals, filaments and ovary. The handmade sections were mounted on slides with water for documentation. The images were obtained with a microscope (Leica DM 500) equipped with a camera (Leica ICC 50), using the software LAS (Leica Application Suite version 3.0 2013).

For the analyses under scanning electron microscopy, flowers at different developmental stages were dehydrated in an acetone series, critical point-dried (Balzers CPD 030) and coated with gold (Balzers SCD 050 Sputter Coater). The samples were examined in a Tabletop Microscope Hitachi (TM 3000) at the Laboratório de Microscopia Eletrônica of Universidade Estadual Paulista (Sao Paulo State University-UNESP), Rio Claro Campus.

Morphological and anatomical data presented here and by Oriani and Scatena (2013) were used to perform a UPGMA cluster analysis, with Jaccard distance coefficient, using DendroUPGMA (Garcia-Vallvè et al. 1999), available at http://genomes.urv.cat/UPGMA/. The cophenetic correlation coefficient was calculated using the same tool. 


\section{Results}

\section{Morphology}

The flowers are grouped in globose inflorescences (Fig. 1a). Each lateral unit of the inflorescence consists of a single flower preceded by several subtending bracts. These units are arranged in a raceme-like structure and are formed acropetally. The flowers are trimerous and pentacyclic (Fig. 1a). The sepals are lanceolate and free (Fig. 1b), and the petals are obovate, free at the top and connate from the base to mid-length, forming a tube (Fig. 1a, b). Filaments are adnate to the corolla tube, but detach from the corolla as the petals become free (Fig. 1c, e). The anthers are dorsifixed (Fig. 1f), poricidal (Fig. 1e) and become rugose as they mature (Fig. 1b, e). The ovary is superior, cylindrical, with a terminal style and a simple stigma (Figs. 1b, d, 5d).

\section{Histology}

The sepals, in surface view, have a smooth cuticle and multicellular, uniseriate trichomes that are scattered on both surfaces (Fig. 1g), but mostly on the adaxial one. In cross section, the epidermal cells have thin walls on the sepal adaxial surface and $U$-shaped thickened walls on the abaxial surface (Fig. 1j, m). The cells of the adaxial epidermis are tabular, have a larger lumen than those of the abaxial one and contain phenolic compounds (Fig. 1m). The cells of the abaxial epidermis may contain phenolic compounds or silica bodies (Fig. 1j, m). The mesophyll is dorsiventral, composed of a parenchymatous tissue facing the sepal adaxial surface and a sclerenchymatous tissue facing the abaxial surface (Fig. 1m). Vascular bundles are collateral (Fig. 1m). The margins of the sepals are formed by the extension of epidermis.

The petals, in surface view, have epidermal cells with sinuous walls. The cuticle is ornamented, except in the basal region of the petals (Fig. 1k, l). Multicellular, uniseriate trichomes occur on both petal surfaces (Fig. 1h, n), mostly on the median and basal regions. In cross section, epidermal cells are rounded and thin-walled and have a larger lumen on the adaxial petal surface than on the abaxial surface (Figs. 1n, 2f, g). Some of these cells contain phenolic compounds (Figs. $1 \mathrm{n}, 2 \mathrm{~g}$ ). The mesophyll is parenchymatous, with collateral vascular bundles (Figs. 1n, 2g). At the petal base, the mesophyll has air canals and phenolic idioblasts (Fig. 1o). The petal margins consist of epidermis only (Fig. 2g).

The anthers are tetrasporangiate and show a prominent connective (Fig. 2a, b, g). Epidermal cells are thin-walled and rounded, being papillate only on the connective (Fig. 2a). All epidermal cells of the anther contain phenolic compounds (Fig. 2a, b). The wall of immature anthers is composed of an epidermis, an endothecium, one to two middle layers and a secretory-type tapetum (Fig. 2a, detail). The middle layers and the tapetum are ephemeral; thus, mature anthers show only an epidermis and an endothecium with spiral thickenings (Fig. $2 b$, detail). The filaments have an epidermis with thin-walled cells, a parenchymatous cortex and a single collateral vascular bundle (Fig. 2c), which extends up to the anther apex. On the free portion of the filament, epidermal cells contain phenolic compounds (Fig. 1c), and multicellular, uniseriate trichomes are found (Figs. 1e, f, i, 2c).

The style has an epidermis with radially elongated cells, whose outer and inner periclinal walls are thickened (Fig. 2d). These epidermal cells may contain phenolic compounds all along the style. The mesophyll is composed of parenchymatous cells and phenolic idioblasts (Fig. 2d). The pollen tube transmitting tissue has small cells with thin walls and intense cytoplasm staining.

The ovary is 3-carpellate (Figs. 2f, 6a-t), with intrusive parietal placentation (Fig. 6s). There are six ovules (two per carpel) on placentas on intruding septa (Fig. 6s). The outer epidermis of the ovary wall consists of radially elongated, thin-walled cells, whereas the inner epidermis consists of rounded cells (Fig. 2e). Only in the apical region of the ovary do the cells of the outer epidermis have thickened anticlinal walls and contain silica bodies. The mesophyll consists of five to eight layers of parenchymatous cells and contains phenolic idioblasts (Fig. 2e). The ovary is vascularised by three dorsal carpellary bundles (Fig. 2f), which run through the style (Fig. 2d) up to the stigma, and by three ventral carpellary bundles, which supply the ovules (Fig. 2f). The ovules are anatropous and bitegmic. Multicellular and uniseriate trichomes occur at the base of the ovary (Fig. 5a).

The morphological and anatomical characteristics of the flowers of Saxofridericia aculeata plus those described by Oriani and Scatena (2013) for other genera of Rapateaceae are presented in Table 1 for comparison.

\section{Histochemistry}

The multicellular, uniseriate trichomes present in the sepals, petals, filaments and around the ovary base secrete a viscous and hyaline exudate (Fig. 3a). This secretion shows positive results for tannic acid $+\mathrm{FeCl}_{3}$ (Fig. 3b) and PAS (Fig. 3c) tests, which evidences its polysaccharidic nature and confirms it is mucilage. The cellular content of the trichomes also stains with Ruthenium Red (Fig. 3d).

The floral secretory trichomes are composed of one basal cell, two flattened collar cells and two to seven elongated cells (Fig. 3b-d). Such trichomes appear at midstage of floral development (Fig. 5a-c), and in the floral 

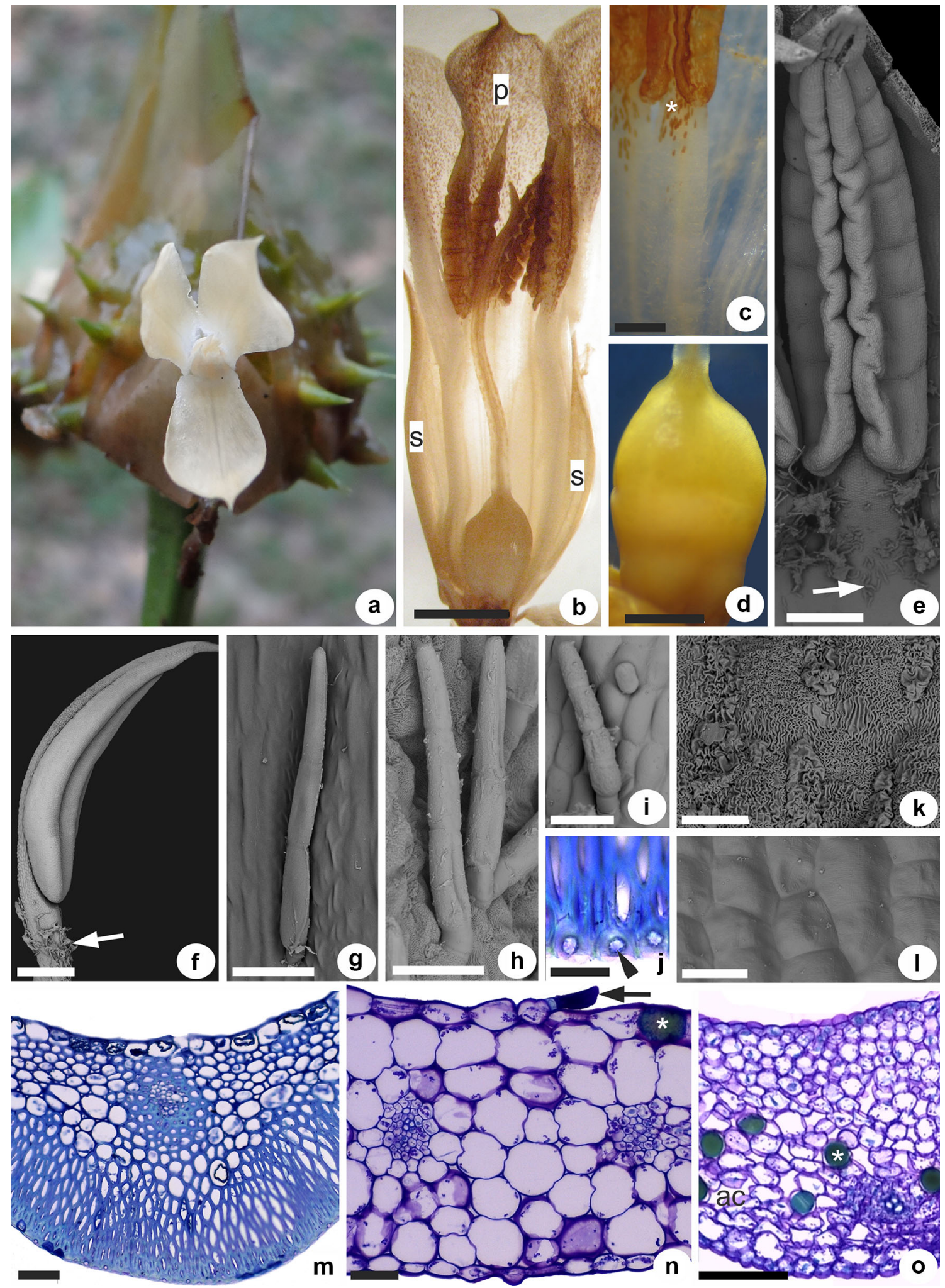

Fig. 1 Morphological and anatomical aspects of the flowers of Saxofridericia aculeata (Rapateaceae), under stereomicroscope (b-d), scanning electron microscope $(\mathbf{e}-\mathbf{i}, \mathbf{k}-\mathbf{l})$ and light microscope (cross sections) (j, m-o). a Inflorescence. b Flower. c Detail of the free portion of the filament. d Ovary. e, f Stamen. $\mathbf{g}$ Sepal trichome. h Petal trichomes. i Filament trichome. $\mathbf{j}$ Detail of the sepal abaxial

epidermis. $\mathbf{k}$, I Detail of the cuticle at the apex and at the base of the petal, respectively. $\mathbf{m}$ Median region of the sepal. $\mathbf{n}$ Median region of the petal. o Basal region of the petal. Scale bars $4 \mathrm{~mm}$ in $\mathbf{b} ; 400 \mu \mathrm{m}$ in $\mathbf{c} ; 1 \mathrm{~mm}$ in $\mathbf{d} ; 800 \mu \mathrm{m}$ in $\mathbf{e}, \mathbf{f} ; 50 \mu \mathrm{m}$ in $\mathbf{g}-\mathbf{i}, \mathbf{m}, \mathbf{o} ; 20 \mu \mathrm{m}$ in $\mathbf{j}-\mathbf{l}$; $100 \mu \mathrm{m}$ in $\mathbf{n}$. $a c$ air canals, $p$ petals, $s$ sepals, arrowhead silica bodies, arrows trichomes, asterisks phenolic compounds 

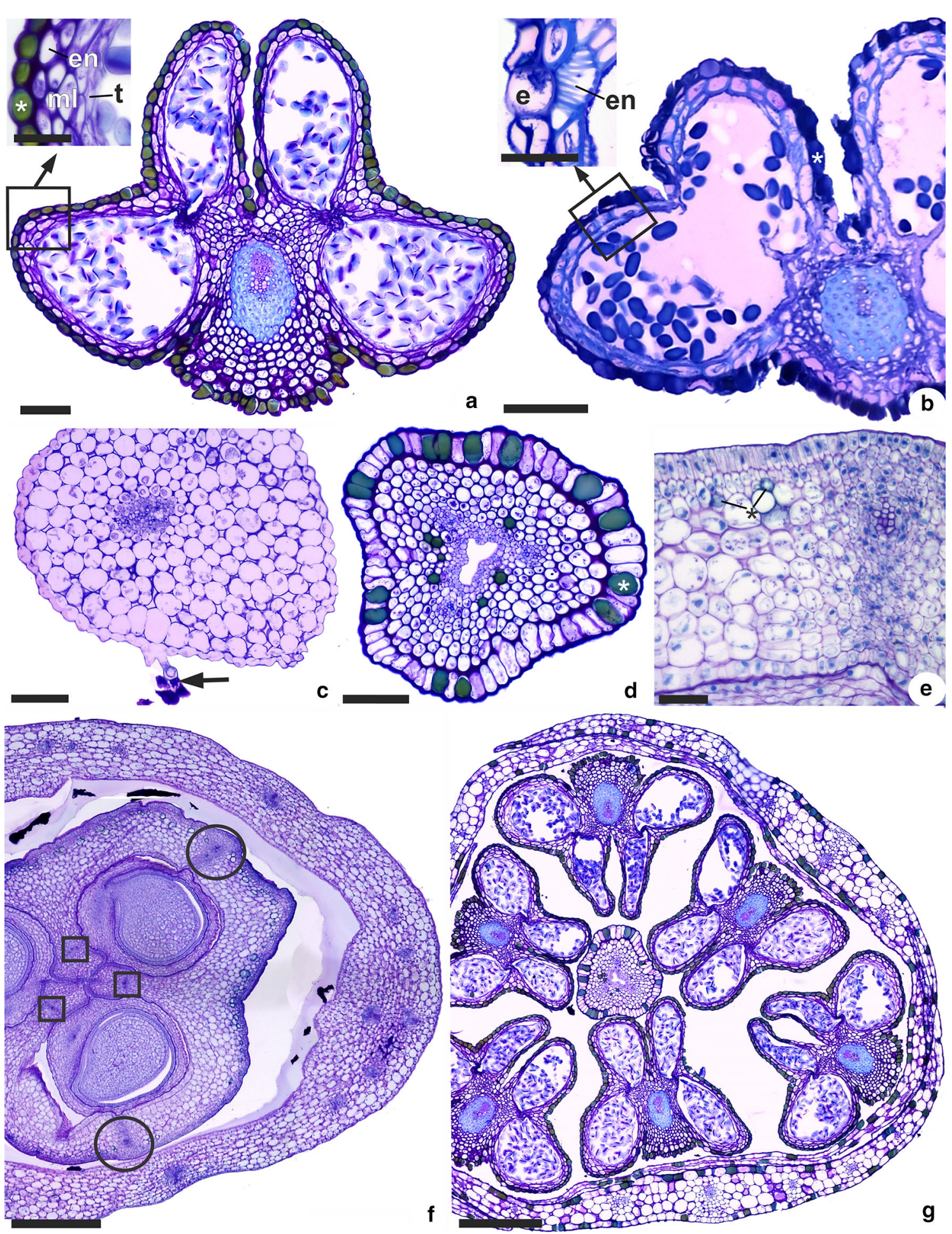

Fig. 2 Cross sections of androecium and gynoecium of Saxofridericia aculeata (Rapateaceae). a Immature anther, with a detail of the anther wall. b Mature anther, with a detail of the anther wall. c Filament. d Style. e Ovary wall. f, g Flower at mid-level and upper level, respectively; the sepals were removed. Scale bars $100 \mu \mathrm{m}$ in

buds, the cells are small and rounded, elongating as the flower develops. Since the cells do not rupture as the exudate is secreted, the trichomes persist after anthesis. a-d; $40 \mu \mathrm{m}$ in a, b (details), e; $400 \mu \mathrm{m}$ in $\mathbf{f}$, g. $e$ epidermis, en endothecium, $m l$ middle layer, $t$ tapetum, asterisks phenolic compounds, arrow trichomes, circles dorsal carpellary bundles, squares ventral carpellary bundles

The histochemical tests also show the presence of starch grains in the mesophyll of sepals, petals, filaments and ovary. In addition, the phenolic content of the idioblasts 
Table 1 Characteristics of the flowers of Rapateaceae that varied among genera

\begin{tabular}{|c|c|c|c|c|c|c|}
\hline Characteristics & $1^{\mathrm{a}}$ & $2^{\mathrm{a}}$ & $3^{\mathrm{a}}$ & $4^{\mathrm{a}}$ & $5^{\mathrm{a}}$ & 0 \\
\hline \multicolumn{7}{|l|}{ Calyx } \\
\hline Dialysepalous (0); gamosepalous (1) & 1 & 1 & 0 & 0 & 0 & 0 \\
\hline Epidermal cells with an ornamented cuticle (0); smooth cuticle (1) & 0 & 0 & 0 & 0 & 0 & 1 \\
\hline Epidermal cells with phenolic compounds: absent (0); on both sepal surfaces (1) & 0 & 0 & 0 & 1 & 1 & 1 \\
\hline Epidermal cells with silica bodies: absent (0); on both sepal surfaces (1); only on the abaxial sepal surface (2) & 1 & 1 & 2 & 0 & 0 & 2 \\
\hline Trichomes: absent (0); on both sepal surfaces (1); only on the adaxial surface (2) & 1 & 1 & 0 & 2 & 0 & 1 \\
\hline Mesophyll: dorsiventral (0); homogeneous (1) & 0 & 1 & 1 & 0 & 0 & 0 \\
\hline \multicolumn{7}{|l|}{ Corolla } \\
\hline Obovate/obcordate $(0)$; lanceolate $(1)$ & 1 & 0 & 0 & 1 & 0 & 0 \\
\hline Petals connate from the base to mid-length ( 0$)$; only basally connate (1); free (2) & 0 & 0 & 1 & 2 & 1 & 0 \\
\hline Epidermal cells with phenolic compounds: absent (0); on both petal surfaces (1) & 0 & 0 & 1 & 1 & 1 & 1 \\
\hline Trichomes: absent (0); on both petal surfaces (1); only on the adaxial surface (2); only on the abaxial surface (3) & 2 & 1 & 0 & 1 & 3 & 1 \\
\hline Idioblasts with phenolic compounds in the mesophyll: absent $(0)$; present $(1)$ & 0 & 0 & 0 & 0 & 1 & 1 \\
\hline \multicolumn{7}{|l|}{ Androecium } \\
\hline Filament: free (0); adnate to the petals (1) & 1 & 1 & 1 & 0 & 1 & 1 \\
\hline Trichomes on the filament: absent (0); present (1) & 0 & 1 & 0 & 0 & 0 & 1 \\
\hline Epidermal cells of the filament with phenolic compounds: absent (0); present (1) & 0 & 0 & 0 & 1 & 1 & 1 \\
\hline Anther insertion: basal (0); dorsifixed (1) & 0 & 0 & 0 & 0 & 0 & 1 \\
\hline Rugose anthers: absent (0); present (1) & 0 & 0 & 0 & 0 & 1 & 1 \\
\hline Anthers with an apical appendage: absent (0); present (1) & 0 & 1 & 0 & 0 & 0 & 0 \\
\hline Epidermal cells of the anthers with phenolic compounds: at the whole extension (0); with a restricted distribution (1) & 0 & 1 & 0 & 1 & 0 & 0 \\
\hline Middle layer of the anther wall: persistent (0); ephemeral (1) & 0 & 0 & 0 & 1 & 1 & 1 \\
\hline Idioblasts with phenolic compounds in the connective: absent (0); present (1) & 0 & 0 & 0 & 1 & 1 & 0 \\
\hline \multicolumn{7}{|l|}{ Gynoecium } \\
\hline Style: centrally basal (0); centrally sub-basal (1); terminal (2) & 0 & 1 & 1 & 2 & 2 & 2 \\
\hline Style with a basal bend: absent (0); present (1) & 1 & 0 & 0 & 0 & 0 & 0 \\
\hline $\begin{array}{l}\text { Epidermal cells of the style with thickened external and internal periclinal walls }(0) \text {; thickened external periclinal wall } \\
\text { (1); thin walls (2) }\end{array}$ & 1 & 1 & 1 & 0 & 2 & 0 \\
\hline Epidermal cells with phenolic compounds at the whole extension of the style (0); with a restricted distribution (1) & 1 & 1 & 1 & 0 & 0 & 0 \\
\hline Grooves in the septal regions of the ovary: absent (0); present (1) & 1 & 0 & 0 & 0 & 0 & 0 \\
\hline Outer epidermis of the ovary with thin cell walls $(0)$; with thick anticlinal cell walls (1) & 0 & 1 & 1 & 0 & 0 & 1 \\
\hline Epidermal cells with silica bodies in the ovary wall: absent (0); restricted to the apex (1) & 0 & 1 & 1 & 0 & 0 & 1 \\
\hline Idioblasts with phenolic compounds in the ovary mesophyll: absent (0); present (1) & 0 & 0 & 0 & 1 & 1 & 1 \\
\hline Mucilage-secreting intraovarian trichomes: absent (0); present (1) & 0 & 0 & 0 & 0 & 1 & 0 \\
\hline Obturator: absent $(0)$; present $(1)$ & 1 & 0 & 0 & 1 & 0 & 0 \\
\hline Ovary with three ovules $(0)$; six ovules (1); numerous ovules (2) & 1 & 0 & 0 & 0 & 2 & 1 \\
\hline Basal placentation (0); intrusive parietal placentation (1) & 0 & 0 & 0 & 0 & 1 & 1 \\
\hline
\end{tabular}

1, Spathanthus; 2, Rapatea; 3, Cephalostemon; 4, Monotrema; 5, Stegolepis; 6, Saxofridericia

${ }^{a}$ Data from Oriani and Scatena (2013); italic values show exclusive characteristics

present in the epidermis of sepals, petals, filaments, anthers and style, and in the mesophyll of petals and ovary is evidenced with the $10 \%$ aqueous $\mathrm{FeCl}_{3}$ test.

\section{Organogenesis}

A single rounded floral meristem is formed in each lateral unit of the inflorescence and is preceded by several subtending bracts (Fig. 4a). Calyx development commences with the initiation of two adaxial and one abaxial sepals (Fig. 4b). After their initiation, the sepals enlarge and, subsequently, rounded petals appear alternating with the sepals (Fig. 4c). The petals become triangular when the androecium is initiated (Fig. 4d) and enlarge (Fig. 4e). The sepals rapidly grow and become lanceolate, with a broad base, enveloping and protecting the inner floral parts (Fig. $4 \mathrm{e}-\mathrm{g}$ ). 

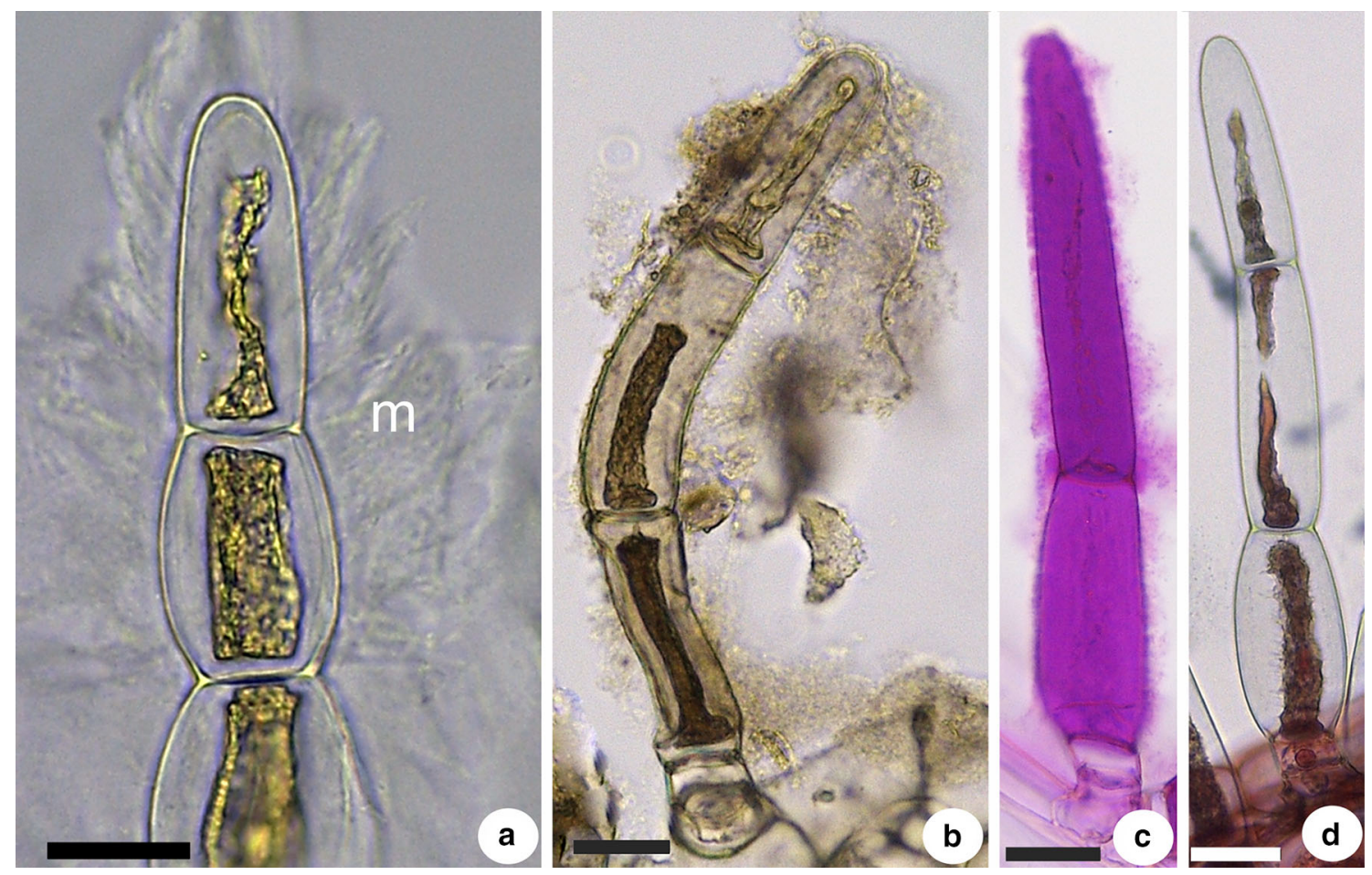

Fig. 3 Floral secretory trichomes of Saxofridericia aculeata (Rapateaceae) submitted to different histochemical tests. a Control. b 5\% tannic acid and $3 \% \mathrm{FeCl}_{3}$. c PAS. d Ruthenium Red. Scale bars $20 \mu \mathrm{m}$ in a-d. $m$ mucilage

The stamens emerge almost simultaneously in two alternating whorls (Fig. 4d, e), the outer whorl alternating with the petals, and have somewhat different shapes (Fig. 4f, g). After stamen initiation, the centre of the floral meristem enlarges and the gynoecium appears as three free carpels (Fig. 4g). Subsequently, the petals enlarge, with their base occupying the entire circumference of the floral bud and enveloping the sexual organs (Fig. $4 \mathrm{~g}-\mathrm{i}$ ). The stamens elongate and the anthers begin to differentiate (Fig. 4h-k).

The young gynoecium is triangular at first (Fig. 4f), and the carpels emerge in the angles (Fig. 4g). The carpels appear as three folded emergences basally connate (Fig. 4h), which grow upward (Fig. 4i). Subsequently, a postgenital fusion occurs at the apex of the carpels, but at the level below the carpels remain free, delimiting intercarpellary slits (Fig. 4j, k). As the ovary is formed, its lower part elongates as a whole via zonal growth, whilst at its upper part the intercarpellary slits are still observed (Figs. 4k, 5a). After the formation of the style, which elongates as a continuous tube (Fig. 5a), the carpel margins at the upper part of the ovary fuse (postgenital fusion), closing the slits completely (Fig. 5d). Cross sections show that the carpels at the upper part of the gynoecium (plicate zone) are initiated separately (Fig. 6a, b) and fuse at later developmental stages through contact between previously free epidermal surfaces (postgenital fusion) (Fig. $6 f-i$, $\mathrm{k}-\mathrm{m}, \mathrm{p}-\mathrm{r}$ ). At the lower part of gynoecium (lower part of symplicate zone and synascidiate zone), the carpels are congenitally united (Fig. 6c-e) and develop as an entire structure (Fig. 6j, n-o, t). The synascidiate zone is short and sterile (Fig. 6e, o, t), whereas the symplicate zone is fertile in the ovary region (Fig. 6s).

Once the gynoecium is formed, the secretory trichomes on the sepals, petals and around the ovary are active (Figs. 5a-c, 6t); the petals are still free (Fig. 5a, b). The connate portion of the corolla elongates only close to anthesis by zonal growth (Fig. 5c). The filaments also elongate adnate to the corolla by zonal growth (Fig. 5d).

\section{Cluster analysis}

From the UPGMA analysis, a dendrogram was generated (Fig. 7), in which two major clusters are present: (1) Monotrema-[Stegolepis-Saxofridericia] and (2) Spathanthus-[Rapatea-Cephalostemon]. In the first major cluster, Saxofridericia (tribe Saxofridericieae) and Stegolepis (tribe Stegolepideae) form a group. Both taxa are placed in the subfamily Saxofridericioideae and have Monotrema (subfamily Monotremoideae) as sister. In the second cluster, Rapatea and Cephalostemon are grouped together, with Spathanthus as sister, and all three genera belong to subfamily Rapateoideae. The cophenetic correlation coefficient for this dendrogram is 0.929 . 

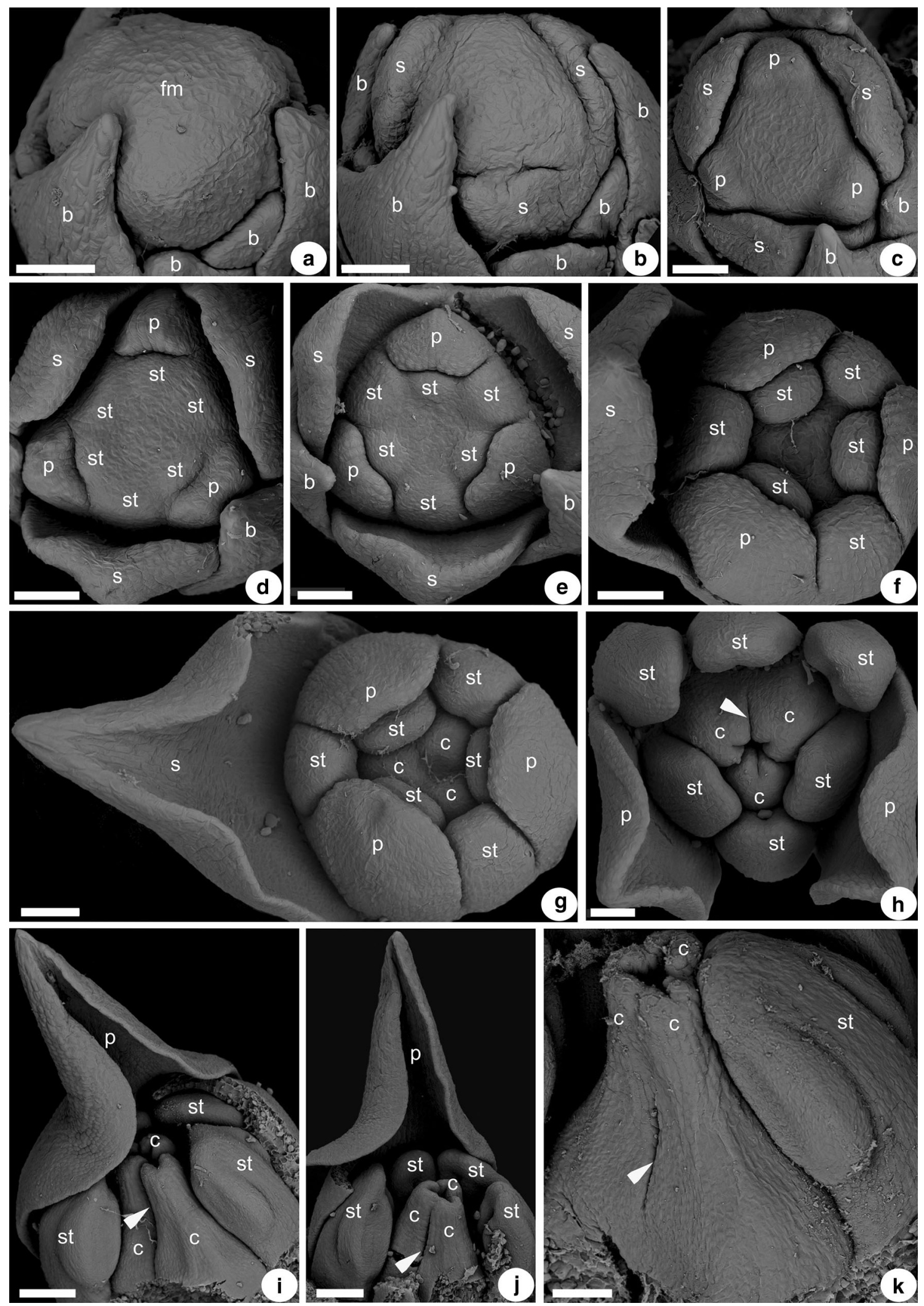
4Fig. 4 Flower development of Saxofridericia aculeata (Rapateaceae) under scanning electron microscope. a Floral meristem surrounded by bracts. b Flower with sepals initiated. c Flower with petals initiated. d, e Flower with stamens initiated. f, g Flower with gynoecium initiated; note that the sepals are lanceolate at this stage and envelope all other floral parts. $\mathbf{h}-\mathbf{j}$ Early development of carpels, which appear as three free organs; note that the petals overgrow the developing sexual organs; sepals removed. k Close-up of gynoecium and stamen, showing postgenital intercarpellary fusion in the upper part of gynoecium. Scale bars $60 \mu \mathrm{m}$ in $\mathbf{a}-\mathbf{h}, \mathbf{k}, 100 \mu \mathrm{m}$ in $\mathbf{i}, \mathbf{j}$. fm floral meristem, $b$ bracteole, $c$ carpel, $p$ petal, $s$ sepal, st stamen, arrowheads intercarpellary region

\section{Discussion}

\section{Floral morphology and anatomy}

The flowers of Saxofridericia aculeata share the following characteristics with other Rapateaceae: secretory trichomes at the base of all floral parts; petals, anthers and style with an ornamented cuticle; petals with epidermal cells with sinuous walls; tetrasporangiate anthers with epidermal cells containing phenolic compounds and an endothecium with spiral thickenings; 3-carpellate, incompletely septate ovary; and bitegmic and anatropous ovules (Oriani and Scatena 2013). Saxofridericia aculeata is distinguished from the remaining Rapateaceae studied by its smooth cuticle on sepals and dorsifixed anthers with a prominent connective. Since Saxofridericieae includes only the genus Saxofridericia, these characteristics may also distinguish the tribe Saxofridericieae, considering that most floral features are constant at generic level (Oriani and Scatena 2013). In addition, our results are in agreement with the morphological characteristics described by Givnish et al. (2004) for the flowers of Saxofridericia regalis.

It is important to highlight that, although the persistent middle layer of the anther wall was considered a diagnostic characteristic for the family (Venturelli and Bouman 1988), in Saxofridericia the middle layer is ephemeral as in Stegolepis and Monotrema (Oriani and Scatena 2013), differentiating these genera from those included in Rapateoideae.

Silica bodies in epidermal cells are considered an apomorphy for Poales (Prychid et al. 2004), and their distribution in stems, leaves and inflorescence axis has taxonomic importance within Rapateoideae (Carlquist 1966; Daltin et al. 2015). Our results show that the silica bodies in flowers are not restricted to Rapateoideae, since they occur in the epidermal cells of sepals and in the ovary wall of Saxofridericia aculeata. In association with a sclerenchymatous tissue, as observed in the sepals, the cells with silica bodies may help to maintain the rigidity of the organ, as reported for other angiosperms (Prychid et al. 2004). This is especially important for the development of $S$. aculeata floral buds, because their sepals need to perforate the bracts enveloping the inflorescence.

The phenolic nature of the idioblasts of S. aculeata floral organs was confirmed by the ferric chloride test and by the green colour that these cells acquired when stained with Toluidine Blue (Ramalingan and Ravindranath 1970). The
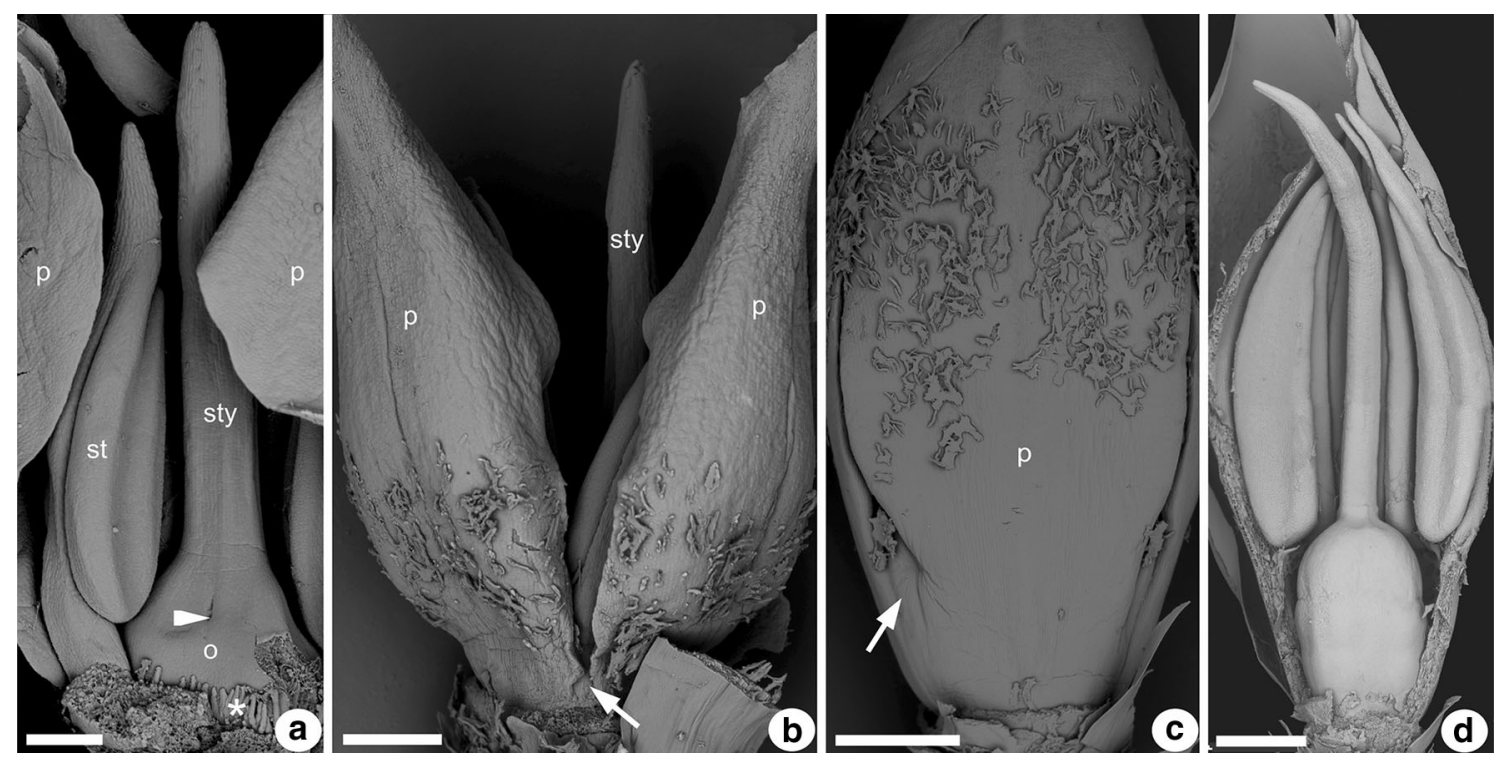

Fig. 5 Flower development of Saxofridericia aculeata (Rapateaceae) under scanning electron microscope; sepals removed. a Differentiation of the stamens and elongation of ovary and style; note the secretory trichomes around the gynoecium and a short intercarpellary slit. b Free petals with secretory trichomes at their base. c Elongation of the connate portion of the petals; the stamens are also adnate to the corolla. d Preanthetic floral bud, with fused petals and carpels. Scale bars $250 \mu \mathrm{m}$ in a, $500 \mu \mathrm{m}$ in b, $1 \mathrm{~mm}$ in c, d. $p$ petal, $o$ ovary, $s t$ stamen, sty style, asterisk trichomes, arrowheads free region between carpels, arrows petal and stamen fusion 

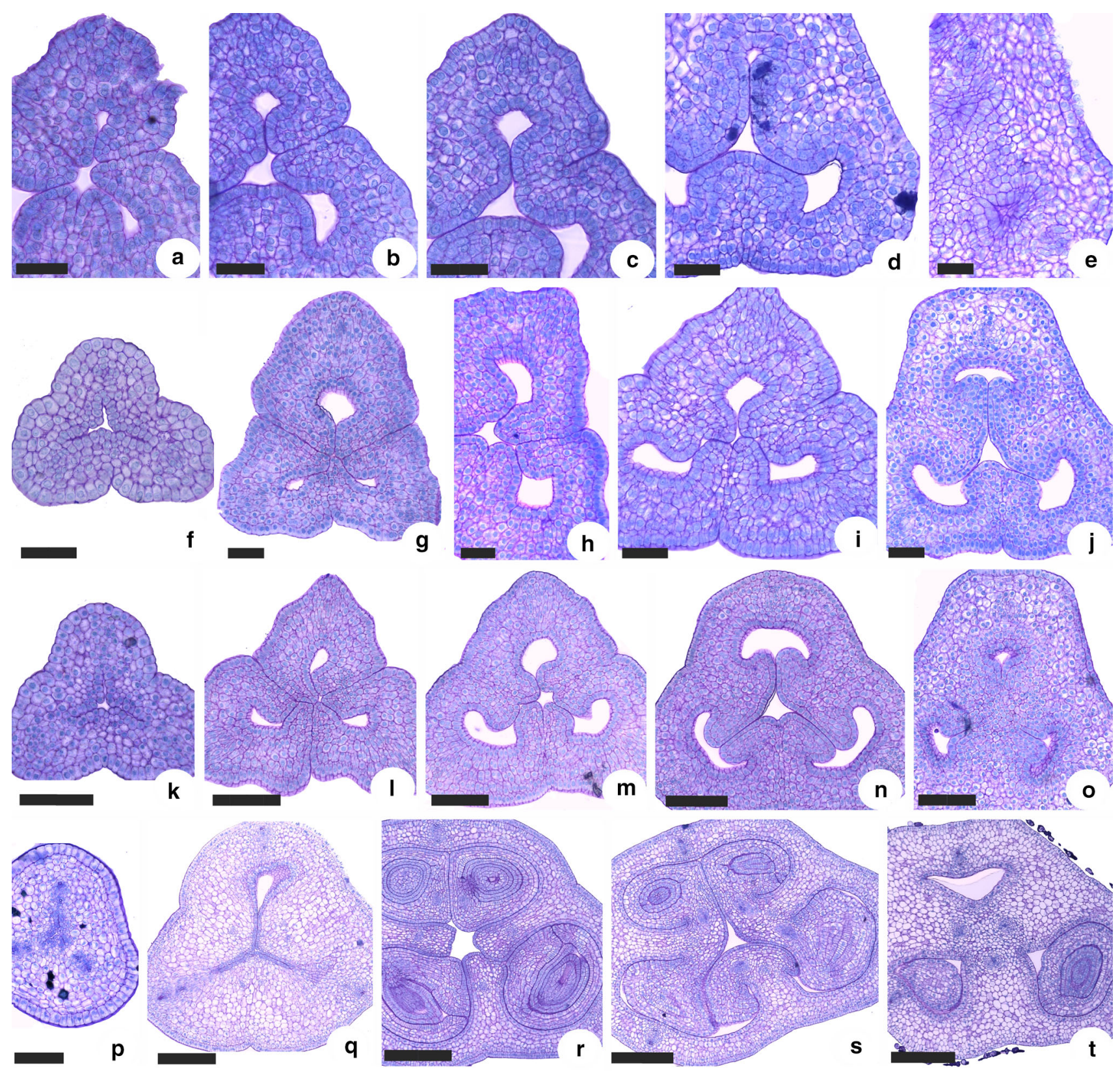

Fig. 6 Cross sections of gynoecium of Saxofridericia aculeata (Rapateaceae) flowers at successive developmental stages. ae Early development of gynoecium, showing the free tips of carpels $(\mathbf{a}, \mathbf{b})$, which are basally connate $(\mathbf{c}-\mathbf{e}) . \mathbf{f}-\mathbf{j}$ Subsequent developmental stages, showing the postgenital fusion occurring at the apex of the carpels (f); the carpels remain free at the upper part of the plicate zone

distribution of cells containing phenolic compounds all over the plant has taxonomic significance for Rapateaceae, since it varies according to genera and subfamilies (Carlquist 1966; Oriani and Scatena 2013; Ferrari et al. 2014; Daltin et al. 2015). The presence of phenolic idioblasts in the sepals, filament and ovary wall distinguishes Monotremoideae and Saxofridericioideae from Rapateoideae. The occurrence of phenolic compounds in the flowers can $(\mathbf{g}, \mathbf{h})$ and are connate at the lower part of the plicate zone $(\mathbf{i}, \mathbf{j})$. $\mathbf{k}$ o At a later developmental stage, the cross sections from the top of the ovary (plicate zone) to its base (synascidiate zone) show that carpels remain free only on top of the ovary (l). p-t Mature gynoecium, with united carpels in both plicate $(\mathbf{p}-\mathbf{s})$ and ascidiate $(\mathbf{t})$ zones. Scale bars $40 \mu \mathrm{m}$ in $\mathbf{a}-\mathbf{e}, 50 \mu \mathrm{m}$ in $\mathbf{f}-\mathbf{j}, 100 \mu \mathrm{m}$ in $\mathbf{k}-\mathbf{p}, 200 \mu \mathrm{m}$ in $\mathbf{q}-\mathbf{t}$

be linked to defence against pathogens, causing the inhibition of their hydrolases (Swain 1977; Nicholson and Hammerschmidt 1992); protection against herbivory, making the plant unpalatable (Levin 1971; Swain 1977; Strack 1997); and attraction of pollinators in flowers (Pereira et al. 2009).

In Saxofridericia aculeata, characteristics such as the poricidal anthers with endothecial thickenings; the 
Fig. 7 Dendrogram obtained from the UPGMA analysis with Jaccard distance coefficient, showing the similarity relationships among the genera of Rapateaceae based on floral characteristics

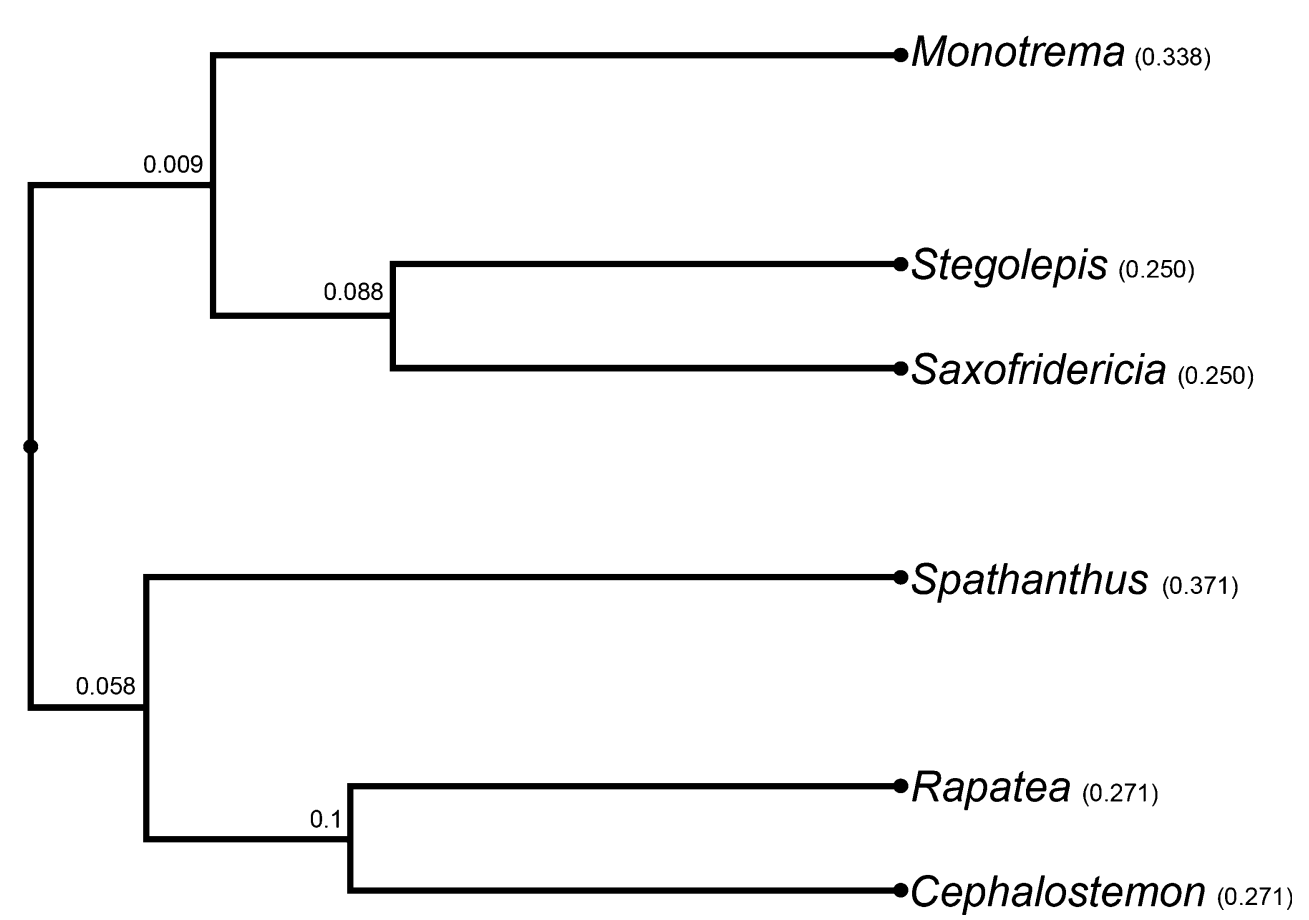

ornamented cuticle of the petals, anthers and style; and the yellow colour of the petals indicate bee pollination, as suggested for other Rapateaceae (Stevenson et al. 1998; Berry 2004; Oriani and Scatena 2013). An ornamented cuticle, a common characteristic of the petals of Rapateaceae flowers (Oriani and Scatena 2013), probably influences how the light is reflected during anthesis, acting synergistically with pigments present in these floral parts to attract pollinators (Gale and Owens 1983; Rudall 1994). In addition, the thick cuticle can also reinforce the cell walls, causing the organs to be steadier (Gale and Owens 1983).

\section{Floral secretory trichomes as colleters}

The definition of colleters is confusing due to the plasticity in their structure and localisation. Colleters show varying morphologies, occur on developing vegetative or reproductive organs, may be vascularised or not and secrete mucilage, usually ceasing their activity as the plant ages (Fahn 1974; Leitão and Cortelazzo 2008; Mayer et al. 2011, 2013; Cardoso-Gustavson et al. 2014). The exudate secreted is viscous and mainly composed of polysaccharides, but may also contain fractions of proteins, lipids and terpenes (Fahn 1974; Miguel et al. 2009; Leitão and Cortelazzo 2008; Mayer et al. 2011, 2013; Cardoso-Gustavson et al. 2014).

Our results demonstrate for the first time the polysaccharidic composition of the abundant exudate secreted by the floral trichomes of Rapateaceae, supporting their characterisation as colleters as given by Oriani and Scatena (2013). Their occurrence on flowers is considered an apomorphy for the family within Poales (Oriani and Scatena 2013). Similar trichomes also occur on developing stems and leaf sheaths of Rapateaceae species (Carlquist 1966, 1969; Stevenson et al. 1998; Ferrari et al. 2014; Daltin et al. 2015).

The floral colleters observed in Saxofridericia aculeata remain intact after anthesis, not rupturing or accumulating mucilage in the subcuticular space. In this case, it is possible that the secretion process occurs through cuticle pores (Wagner 1991; Ascensão and Pais 1998; Ascensão et al. 1999; Fahn 2000; Tozin et al. 2015), but further studies are necessary to investigate this process. Since $S$. aculeata occurs in the forest understory, a shadowed and humid habitat, and the flowers are numerous on the inflorescences, the abundant mucilage probably allows gliding of flowers and floral parts over each other during growth (Werker 2000; Leitão and Cortelazzo 2008; Mayer et al. 2011; Oriani and Scatena 2013). It may also play an ecological role, involving somehow interactions with microorganisms (Werker 2000).

\section{Organogenesis}

Although the flowers of Saxofridericia aculeata are heterochlamydeous, they show the typical monocotyledon flower structure (Remizowa et al. 2010). The stamens are adnate to the petals in the mature flower, but grow from different primordia. There is no correlation between stamen-petal fusion and their origin as one or two distinct structures, considering that this character is homoplastic for the monocots (Remizowa et al. 2012). Floral development 
studies in Poales are scarce, but in Xyridaceae and Eriocaulaceae stamens are adnate to the petals and are initiated in a common primordium (Stützel 1990; Remizowa et al. 2012), whereas in Bromeliaceae the first stages of flower development are similar to those observed in Saxofridericia aculeata, with petals and stamens growing separately (Sajo et al. 2004).

In Saxofridericia aculeata, the corolla has two morphologically distinct parts, separated by the stamen insertion on the corolla: an upper part, composed of free petals, and a lower part congenitally fused, forming a tube with the epipetalous stamens. The formation of the corolla tube is usually a result of zonal growth, which is the activity of meristematic cells between floral parts, connecting them and/or different whorls (Verbeke 1992). Corolla tube formation by zonal growth has been reported for a large number of angiosperms (e.g. Boke 1948; Kaplan 1968; Nishino 1983; Verbeke 1992), and it can take place early in development or at late developmental stages as observed in S. aculeata. The mechanism of congenital fusion lies in the establishment of a basal or intercalary meristem, which replaces the apical growth normally responsible for the formation of separate organs (Verbeke 1992).

In relation to the gynoecium, in most Poalean families studied the intercarpellary fusion is exclusively congenital, with the gynoecium appearing as a solid or annular structure, such as in Xyridaceae (Stützel 1990; Remizowa et al. 2012) and Cyperaceae (Reynders et al. 2012). In Saxofridericia aculeata, however, the mature gynoecium is the product of both congenital and postgenital fusion events. Three carpels are initiated in the angles of the remaining floral apex as folded emergences, which are basally continuous. Whereas the lower part of the ovary is formed by zonal growth (congenital carpel fusion), at its upper part the carpels fuse postgenitally. A similar process occurs in other monocots, such as in some species of Asparagaceae (Remizowa et al. 2010) and Tofieldiaceae (Remizowa et al. 2011), where carpels are congenitally united in the ascidiate zone and partially or completely postgenitally united in the plicate zone. Also in Bromeliaceae, the carpels are initiated as three free structures at the early developmental stages (Sajo et al. 2004), indicating that the intercarpellary fusion, at least in the upper part of gynoecium, is postgenital. Such characteristic may be an evidence of the close phylogenetic relationship between these two families.

There is a correlation between postgenital intercarpellary fusion and presence of septal nectaries (van Heel 1988; Remizowa et al. 2010). If carpels are initiated free, the formation of the nectaries may occur in the septal regions before intercarpellary fusion; whereas if carpels are united from the beginning, nectary formation in the gynoecium is inhibited (van Heel 1988). Although very common in monocots, septal nectaries have been lost in Poales (Smets et al. 2000), occurring only in Bromeliaceae and Rapateaceae. Whereas all Bromeliaceae species have septal nectaries (Böhme 1988; Sajo et al. 2004), in Rapateaceae such structures are present only in the most derived tribe Schoenocephalieae (Berry 2004; Givnish et al. 2004). Since the flowers of Saxofridericia aculeata show partially postgenital intercarpellary fusion and do not have septal nectaries, we may assume that the floral nectaries were lost in Poales before the shift from postgenital to exclusively congenital intercarpellary fusion. The formation of intercarpellary slits resembling a septal nectary in S. aculeata is interpreted as a reminiscence of the septal nectaries present in Bromeliaceae and Schoenocephalieae.

Also in Tofieldiaceae, the hypothesis that evolutionary loss of septal nectaries is associated with a shift from postgenital (or partially postgenital) to exclusively congenital carpel fusion is challenged (Remizowa et al. 2011). Whereas Tofieldia, Triantha and Pleea have septal nectaries, in Isidrogalvia and Harperocallis septal nectaries are absent, although the fertile plicate zones of the carpels are postgenitally united (Remizowa et al. 2011). According to the authors, species of Isidrogalvia and Harperocallis possess abundant secretory tuberculate emergences (glands) on the carpel surface, which could substitute for septal nectaries. In the same way, for Rapateaceae we hypothesise that the septal nectaries would have been replaced by the apomorphic floral secretory trichomes. However, studies on floral anatomy and biology are necessary to test such hypotheses, especially for the species of Schoenocephalieae.

The flowers of Schoenocephalieae produce considerable amounts of nectar and show a red and tubular corolla, with smooth-walled anthers that are sensitive to touch and easily liberate the pollen grains (Berry 2004). Such features suggest a bird pollination syndrome as reported by Berry (2004), who observed hummingbirds visiting the flowers of representatives of the three genera included in this tribe. Such features also distinguish Schoenocephalieae species from the remaining Rapateaceae, which are bee-pollinated (Stevenson et al. 1998; Berry 2004), and reflect the pollinator selective pressure acting on flower morphology and anatomy.

\section{Phylogenetic and taxonomic considerations}

Rapateaceae appear as an early diverging family within Poales, closely related to Bromeliaceae, in most phylogenetic studies (Davis et al. 2004; Linder and Rudall 2005; Chase et al. 2006; Givnish et al. 2010). Although the family has been recently placed as sister to Mayacaceae in the cyperid clade (Bouchenak-Khelladi et al. 2014), Rapateaceae and Mayacaceae flowers share only 
few characteristics as the poricidal anthers (Stevenson 1998). Mayacaceae flowers are solitary and tetracyclic, showing free petals and stamens, an isostemonous androecium, anther wall with an endothecium lacking thickenings, parietal placentation, orthotropous and tenuinucellate ovules (Venturelli and Bouman 1986; Oriani and Scatena 2013). Based on these differences, and also considering both the presence of floral nectaries and the similarity between Rapateaceae and Bromeliaceae in relation to floral organogenesis (Sajo et al. 2004), our data strongly support the early diverging position of Rapateaceae in Poales.

Rapateaceae were formerly divided into two subfamilies: Rapateoideae, comprising the tribes Rapateeae and Monotremeae; and Saxofridericioideae, comprising the tribes Saxofridericieae and Schoenocephalieae (Maguire 1958, 1965). After the identification of non-monophyletic groups inside the family (Givnish et al. 2000, 2004), the tribe Monotremeae was erected in the subfamily Monotremoideae, and the new tribe Stegolepideae was created, comprising the genera previously included in Saxofridericieae, except for Saxofridericia (Givnish et al. 2004). Thus, three subfamilies and five tribes are currently accepted.

In this context, our results on floral anatomy proved to be useful for the taxonomy of the family and also for the understanding of infrafamilial relationships. The dendrogram generated by the UPGMA analysis reflects the groups that emerged in the phylogenetic analyses of the family based on molecular data (Givnish et al. 2000, 2004). Saxofridericia (Saxofridericieae) shares more characteristics with Stegolepis (Stegolepideae) than with the remaining genera studied, corroborating their close phylogenetic relationship. Both genera are included in Saxofridericioideae and share more characteristics with Monotrema than with Rapateoideae, corroborating the placement of Monotrema in Monotremoideae, sister to Saxofridericioideae (Givnish et al. 2004).

Acknowledgements The authors thank FAPESP-Fundação de Amparo à Pesquisa do Estado de São Paulo (Process Number 2014/22991-1) and CNPq-Conselho Nacional de Desenvolvimento Científico e Tecnológico (Process Number 168277/2014-0) for financial support. We also thank Dr Alessandra Ike Coan for collecting the plant material; the technicians Monika Iamonte and Antonio Teruyoshi Yabuki for their support at the Laboratório de Microscopia Eletrônica, UNESP; and Prof. Peter Endress and the anonymous reviewers for their critical comments that improved the manuscript.

\section{Compliance with ethical standards}

Conflict of interest The authors declare that there is no conflict of interest.

\section{References}

Ascensão L, Pais MS (1998) The leaf capitate trichomes of Leonotis leonurus: histochemistry, ultrastructure and secretion. Ann Bot (Oxford) 81:263-271. doi:10.1006/anbo.1997.0550

Ascensão L, Mota L, Castro MM (1999) Glandular trichomes on the leaves and flowers of Plectranthus ornatus: morphology, distribution and histochemistry. Ann Bot (Oxford) 84:437-447. doi:10.1006/anbo.1999.0937

Berry PE (2004) Rapateaceae. In: Berry PE, Yatskievych K, Holst BK (eds) Flora of the venezuelan Guayana, Poaceae-Rubiaceae, vol 8. Missouri Botanical Garden Press, St. Louis, pp 413-472

Böhme S (1988) Bromelienstudien III. Vergleichende Untersuchungen zu Bau, Lage und Systematischer Verwertbarkeit der Septalnektarien von Bromeliaceen. Trop Subtrop Pflanzenwelt 62:119-274

Boke NH (1948) Development of the perianth in Vinca rosea L. Amer J Bot 35:413-423

Bouchenak-Khelladi Y, Muasya AM, Linder HP (2014) A revised evolutionary history of Poales: origins and diversification. Bot $\mathbf{J}$ Linn Soc 175:4-16. doi:10.1111/boj.12160

Bremer K (2002) Gondwanan evolution of the grass alliance of families (Poales). Evolution 56:1374-1387. doi:10.1111/j.00143820.2002.tb01451.x

Cardoso-Gustavson P, Campbell LM, Mazzoni-Viveiros SC, Barros F (2014) Floral colleters in Pleurothallidinae (Epidendroideae: Orchidaceae). Amer J Bot 101:587-597. doi:10.3732/ajb. 1400012

Carlquist S (1966) Anatomy of Rapateaceae-roots and stems. Phytomorphology 16:17-38

Carlquist S (1969) Rapateaceae. In: Tomlinson PB (ed) Anatomy of the monocotyledons, Commelinales-Zingiberales. Oxford University Press, London, pp 129-145

Chase MW, Fay MF, Devey DS, Maurin O, Rønsted N, Davies TJ, Pillon Y, Petersen G, Seberg O, Tamura MN, Asmussen CB, Hilu K, Borsch T, Davis JI, Stevenson DW, Pires JC, Givnish TJ, Sytsma KJ, McPherson MA, Graham SW, Rai HS (2006) Multigene analyses of monocot relationships: a summary. Aliso 23:62-74

Daltin AL, Scatena VL, Oriani A (2015) Leaf and inflorescence axis anatomy of Brazilian species of Rapateoideae (Rapateaceae, Poales). Anais Acad Brasil Ci 87:157-171. doi:10.1590/00013765201520140071

Davis JI, Stevenson DW, Petersen G, Seberg O, Campbell LM, Freudenstein JV, Goldman DH, Hardy CR, Michelangeli FA, Simmons MP, Specht CD, Vergara-Silva F, Gandolfo M (2004) Phylogeny of the monocots, as inferred from $r b c \mathrm{~L}$ and atp $\mathrm{A}$ sequence variation, and a comparison of methods for calculating jackknife and bootstrap value. Syst Bot 29:467-510. doi:10. 1600/0363644041744365

Endress PK (1990) Patterns of floral construction in ontogeny and phylogeny. Biol J Linn Soc 39:153-175. doi:10.1111/j.10958312.1990.tb00509.x

Endress PK (1994) Diversity and evolutionary biology of tropical flowers. Cambridge University Press, Cambridge. doi:10.1046/j. 1420-9101.1996.9010120.x

Endress PK (2011) Evolutionary diversification of the flowers in angiosperms. Amer J Bot 98:370-396. doi:10.3732/ajb.1000299

Fahn A (1974) Plant anatomy. Pergamon Press, Oxford

Fahn A (2000) Structure and function of secretory cells. Advances Bot Res 31:37-75. doi:10.1016/S0065-2296(00)31006-0

Feder N, O'Brien TP (1968) Plant microtechnique: some principles and new methods. Amer J Bot 55:123-142. doi:10.2307/ 2440500 
Ferrari RC, Scatena VL, Oriani A (2014) Leaf and inflorescence peduncle anatomy: a contribution to the taxonomy of Rapateaceae. Pl Syst Evol 300:1579-1590. doi:10.1007/s00606-0140984-1

Fisher DB (1968) Protein staining of ribboned epon sections for light microscopy. Histochemie 16:92-96. doi:10.1007/BF00306214

Gale RMO, Owens SJ (1983) Cell distribution and surface morphology in petals, androecia and styles of Commelinaceae. Bot $\mathrm{J}$ Linn Soc 87:247-262. doi:10.1111/j.1095-8339.1983.tb00993.x

Garcia-Vallvè S, Palau J, Romeu A (1999) Horizontal gene transfer in glycosyl hydrolases inferred from codon usage in Escherichia coli and Bacillus subtilis. Molec Biol Evol 16:1125-1134

Gerrits PO, Smid L (1983) A new, less toxic polymerization system for the embedding of soft tissues in glycol methacrylate and subsequent preparing of serial sections. J Microscopy 132:81-85. doi:10.1111/j.1365-2818.1983.tb04711.x

Givnish TJ, Evans TM, Zjhra ML, Patterson TB, Berry PE, Sytsma KJ (2000) Molecular evolution, adaptive radiation, and geographic diversification in the amphiatlantic family Rapateaceae: evidence from $n d h \mathrm{~F}$ sequences and morphology. Evolution 54:1915-1937. doi:10.1111/j.0014-3820.2000.tb01237.x

Givnish TJ, Millam KC, Evans TM, Hall JC, Pires JC, Berry PE, Sytsma KJ (2004) Ancient vicariance or recent long-distance dispersal? Inferences about phylogeny and South AmericanAfrican disjunctions in Rapateaceae and Bromeliaceae based on ndhF sequence data. Int J Pl Sci 165:35-54. doi:10.1086/421067

Givnish TJ, Ames M, McNeal JR, McKain MR, Steele PR, dePamphilis CW, Graham SW, Pires JC, Stevenson DW, Zomlefer WB, Briggs BG, Duvall MR, Moore MJ, Heaney JM, Soltis DE, Soltis PS, Thiele K, Leebens-Mack JH (2010) Assembling the tree of the monocotyledons: plastome sequence phylogeny and evolution of Poales. Ann Missouri Bot Gard 97:584-616. doi:10.3417/2010023

Jensen WA (1962) Botanical histochemistry. W. H. Freeman and Company, San Francisco. doi:10.1126/science.140.3567.634-a

Johansen DA (1940) Plant microtechnique. McGraw-Hill, New York

Kaplan DR (1968) Structure and development of the perianth in Downingia bacigalupii. Amer J Bot 55:406-420

Leitão CAE, Cortelazzo AL (2008) Structural and histochemical characterisation of the colleters of Rodriguezia venusta (Orchidaceae). Austral J Bot 56:161-165. doi:10.1071/BT07114

Levin DA (1971) Plant phenolics: an ecological perspective. Amer Naturalist 105:157-181. doi:10.1086/282712

Linder HP, Rudall PJ (2005) Evolutionary history of Poales. Annual Rev Ecol Evol Syst 36:107-124. doi:10.1146/annurev.ecolsys. 36.102403.135635

Maguire B (1958) Rapateaceae. The botany of the Guayana Highland. Part III. Mem New York Bot Gard 10:19-49

Maguire B (1965) Rapateaceae. The botany of the Guayana Highland. Part VI. Mem New York Bot Gard 12:69-102

Mayer JLS, Cardoso-Gustavson P, Appezzato-Da-Glória B (2011) Colleters in monocots: new record for Orchidaceae. Flora 206:185-190. doi:10.1016/j.flora.2010.09.003

Mayer JLS, Carmello-Guerreiro SM, Mazzafera P (2013) A functional role for the colleters of coffee flowers. AOB Plants 5:plt029. doi:10.1093/aobpla/plt029

Miguel EC, Moraes DG, Cunha M (2009) Stipular colleters in Psychotria nuda (Cham. \& Schltdl.) Wawra (Rubiaceae): micromorphology, anatomy and cristals microanalysis. Acta Bot Brasil 23:1034-1039. doi:10.1590/S0102-33062009000 400013

Monteiro RF (2015) Rapateaceae. Lista de espécies da flora do Brasil - Jardim Botânico do Rio de Janeiro. Available at: http:// floradobrasil.jbrj.gov.br/jabot/floradobrasil/FB205. Accessed 11 Aug 2016
Nicholson RL, Hammerschmidt R (1992) Phenolic compounds and their role in disease resistance. Annual Rev Phytopathol 30:369-389. doi:10.1146/annurev.py.30.090192.002101

Nishino E (1983) Corolla tube formation in the Tubiflorae and Gentianales. Bot Mag Tokyo 96:223-243. doi:10.1007/ BF02499003

O'Brien TP, Feder N, McCully ME (1964) Polychromatic staining of plant cell walls by Toluidine Blue O. Protoplasma 59:368-373

Oriani A, Scatena VL (2013) The taxonomic value of floral characters in Rapateaceae (Poales-Monocotyledons). Pl Syst Evol 299:291-303. doi:10.1007/s00606-012-0721-6

Pereira DM, Valentão P, Pereira JA, Andrade PB (2009) Phenolics: from chemistry to biology. Molecules 14:2202-2211. doi:10. 3390/molecules14062202

Prychid CJ, Rudall PJ, Gregory M (2004) Systematics and biology of silica bodies in monocotyledons. Bot Rev 69:377-440. doi:10. 1663/0006-8101(2004)069[0377:SABOSB]2.0.CO;2

Ramalingan K, Ravindranath MH (1970) Histochemical significance of green metachromasia to Toluidine Blue. Histochemie 24:322-327. doi:10.1007/BF00278217

Remizowa MV, Sokoloff DD, Rudall PJ (2010) Evolutionary history of the monocot flower. Ann Missouri Bot Gard 97:617-645. doi: $10.3417 / 2009142$

Remizowa MV, Sokoloff DD, Campbell LM, Stevenson DW, Rudall PJ (2011) Harperocallis is congeneric with Isidrogalvia (Tofieldiaceae, Alismatales): evidence from comparative floral morphology. Taxon 60:1076-1094

Remizowa MV, Kuznetsov AN, Kuznetsova SP, Rudall PJ, Nuraliev MS, Sokoloff DD (2012) Flower development and vasculature in Xyris grandis (Xyridaceae, Poales); a case study for examining petal diversity in monocot flowers with a double perianth. Bot J Linn Soc 170:93-111. doi:10.1111/j.1095-8339.2012.01267.x

Reynders M, Vrijdaghs A, Larridon I, Huygh W, Leroux O, Muasya AM, Goetghebeur P (2012) Gynoecial anatomy and development in Cyperoideae (Cyperaceae, Poales): congenital fusion of carpels facilitates evolutionary modifications in pistil structure. Pl Ecol Evol 145:96-125. doi:10.5091/plecevo.2012.675

Ronse Decraene LP, Linder HP, Smets EF (2002) Ontogeny and evolution of the flowers of South African Restionaceae with special emphasis on the gynoecium. Pl Syst Evol 231:225-258. doi:10.1007/s006060200021

Rudall PJ (1994) Anatomy of flowering plants. Cambridge University Press, New York. doi:10.1017/CBO9780511801709

Rudall PJ, Wolfgang S, Cunniff J, Kellogg EA, Briggs BG (2005) Evolution of reproductive structures in grasses (Poaceae) inferred by sister-group comparison with their putative closest living relatives, Ecdeiocoleaceae. Amer J Bot 92:1432-1443. doi:10.3732/ajb.92.9.1432

Sajo MG, Rudall PJ (2012) Morphological evolution in the graminid clade: comparative floral anatomy of the grass relatives Flagellariaceae and Joinvilleaceae. Bot J Linn Soc 170:393-404. doi:10.1111/j.1095-8339.2012.01283.x

Sajo MG, Rudall PJ, Prychid CJ (2004) Floral anatomy of Bromeliaceae, with particular reference to the evolution of epigyny and septal nectaries in commelinid monocots. Pl Syst Evol 247:215-231. doi:10.1007/s00606-002-0143-0

Sajo MG, Longhi-Wagner H, Rudall PJ (2007) Floral development and embryology in the early-divergent grass Pharus. Int J Pl Sci 168:181-191. doi:10.1086/509790

Smets EF, Ronse Decraene LP, Caris P, Rudall PJ (2000) Floral nectaries in monocotyledons: distribution and evolution. In: Wilson KL, Morrison DA (eds) Monocots: systematics and evolution. CSIRO, Melbourne, pp 230-240

Sokoloff DD, Remizowa MV, Linder HP, Rudall PJ (2009) Morphology and development of the gynoecium in 
Centrolepidaceae: the most remarkable range of variation in Poales. Amer J Bot 96:1925-1940. doi:10.3732/ajb.0900074

Soltis DE, Soltis PS, Albert VA, Oppenheimer DG, Hong Ma CW, Frohlich MW, Theißen G (2002) Missing links: the genetic architecture of flower and floral diversification. Trends Pl Sci 7:22-31. doi:10.1016/S1360-1385(01)02098-2

Stevenson DW (1998) Mayacaceae. In: Kubitzki K (ed) The families and genera of vascular plants-IV monocotyledons. Springer, Berlin, pp 294-296. doi:10.1007/978-3-662-03531-3

Stevenson DW, Colella M, Boom B (1998) Rapateaceae. In: Kubitzki $\mathrm{K}$ (ed) The families and genera of vascular plants-IV monocotyledons. Springer, Berlin, pp 415-424. doi:10.1007/978-3662-03531-3

Strack D (1997) Phenolic metabolism. In: Dey PM, Harbore JB (eds) Plant biochemistry. Academic Press, San Diego, pp 387-390

Stützel T (1990) "Appendices" am Gynoeceum der Xyridaceen. Morphogenie, Funktion und systematische Bedeutung. Beitr Biol Pflanzen 65:275-299

Swain T (1977) Secondary compounds as protective agents. Annual Rev Pl Physiol 28:479-501. doi:10.1146/annurev.pp.28.060177. 002403

Tozin LRS, Carvalho SF, Machado SR, Rodrigues TM (2015) Glandular trichome diversity on leaves of Lippia origanoides Kunth and Lippia stachyoides Cham. (Verbenaceae): morphology, histochemistry and ultrastructure. Botany 93:297-306. doi:10.1139/cjb-2014-0251

Tucker S (1992) The role of floral development in studies of legume evolution. Canad J Bot 70:692-700. doi:10.1139/b92-089
Tucker S (1997) Floral evolution, development, and convergence: the hierarchical-significance hypothesis. Int J Pl Sci 158(6 Suppl): S143-S161

van Heel WA (1988) On the development of some gynoecia with septal nectaries. Blumea 33:477-504

Venturelli M, Bouman F (1986) Embryology and seed development in Mayaca fluviatilis (Mayacaceae). Acta Bot Neerl 35:497-516. doi:10.1111/j.1438-8677.1986.tb00489.x

Venturelli M, Bouman F (1988) Development of ovule and seed in Rapateaceae. Bot J Linn Soc 97:267-294. doi:10.1111/j.10958339.1988.tb01584.x

Verbeke JA (1992) Fusion events during floral morphogenesis. Annual Rev Pl Physiol Pl Molec Biol 43:583-598. doi:10.1146/ annurev.pp.43.060192.003055

Vrijdaghs A, Goetghebeur P, Muasya AM, Caris P, Smets E (2005) Floral ontogeny in Ficinia and Isolepis (Cyperaceae), with focus in the nature and origin of the gynophore. Ann Bot (Oxford) 96:1247-1264. doi:10.1093/aob/mci276

Vrijdaghs A, Muasya AM, Goetghebeur P, Caris P, Nagels A, Smets E (2009) A floral ontogenetic approach to questions of homology within the Cyperoideae (Cyperaceae). Bot Rev 75:30-51. doi:10. 1007/s12229-008-9021-9

Wagner GE (1991) Secreting glandular trichomes: more than just hairs. Pl Physiol 96:675-679. doi:10.1104/pp.96.3.675

Werker E (2000) Trichome diversity and development. Advances Bot Res 31:1-35. doi:10.1016/S0065-2296(00)31005-9 